Elżbieta Szubertowska

Uniwersytet Kazimierza Wielkiego w Bydgoszczy

\title{
Nauczyciel muzyki - zawód czy misja
}

Dyskusje na temat nauczyciela podejmowane w różnych środowiskach budzą zróżnicowane emocje. Inaczej ocenia go ten, kto czując powołanie, sam zadecydował o wyborze tego zawodu, a inaczej widzi go osoba podejmująca tę działalność z konieczności. Na ogół wiadomo, że w obecnych czasach zawód nauczyciela, człowieka mało zarabiającego, poddawanego ostrym krytykom, obarczanego winą za wszystkie niepowodzenia szkolne przez rodziców i środowisko - nie jest atrakcyjny. Od nauczyciela wymaga się nie tylko wiedzy i umiejętności, ale też zdeterminowania i woli ciągłego pokonywania wielu trudności, które jego pracy towarzyszą. Moja refleksja dotyczy tylko nauczyciela muzyki, którego zadaniem, według definicji Dzierżymira Jankowskiego ${ }^{1}$, jest wprowadzanie człowieka w świat wartości uznanych za szczytne ideały i osiągnięcia kultury europejskiej i światowej, a ściślej wychowanie go do kontaktu ze sztuką. Edukacja muzyczna to w głównej mierze przygotowanie wychowanka „do uczestnictwa w kulturze symbolicznej w drodze kształtowania kompetencji kulturalnej, stanowiącej psychologiczną podstawę aktywności jednostki w świecie kultury"2. Czy zatem w tak ujętej edukacji estetycznej, w tym muzycznej, można mówić tylko o wykonywaniu zawodu przez nauczyciela, czy o podjęciu się przez niego misji przekazywania wartości i ideałów, które stanowią o naszej kulturze, są podstawą naszej narodowej tożsamości?

Rozwinięcie myśli zasygnalizowanej w tytule wymaga zatrzymania się na kilku ważnych zagadnieniach. Przede wszystkim należy sobie zadać pytania: kiedy, w jakich sytuacjach, wykonywanie zawodu nauczyciela muzyki jest wypełnieniem szczególnego posłannictwa, czym powinien odznaczać się nauczyciel, by jego misja była skuteczna, a także co jest przedmiotem i celem tej misji? Szukanie odpowiedzi na te pytania skłania nas do przyj-

\footnotetext{
${ }^{1}$ D. Jankowski, Edukacja kulturalna - aktywność artystyczna, Poznań 1996, s. 46.

${ }^{2}$ Ibidem.
} 
rzenia się nauczycielowi w kontekście podejmowanych przez niego działań oraz do uświadomienia sobie ich specyfiki.

Warto w tym miejscu przypomnieć niektóre fakty $\mathrm{z}$ historii edukacji muzycznej w naszym kraju, by móc lepiej ocenić aktualną sytuację w tej dziedzinie i wynikające z niej posłannictwo nauczyciela.

Podstawową i najbardziej dostępną wszystkim ludziom formą kontaktu z muzyką od zarania dziejów był śpiew. Stanowił on punkt wyjścia i podstawę różnorakiej działalności muzycznej, przyczyniał się do krzewienia kultury humanistycznej, kultury języka, patriotyzmu, odgrywał duże znaczenie w kontaktach międzyludzkich, w pielęgnowaniu przyjaźni. Dostrzegano i doceniano jego wartość w życiu człowieka i jego rolę w wychowaniu. Nic dziwnego, że kontakt $\mathrm{z}$ tą sztuką uczyniono ważnym przedmiotem nauki szkolnej. Już w wiekach XI i XII w szkołach katedralnych i klasztornych, a od XIII wieku również w szkołach parafialnych, do których uczęszczały dzieci różnych stanów, uczono jednogłosowych pieśni, także ludowych, nie tylko metodą pamięciową, ale także i za pomocą nut ${ }^{3}$. W Polsce szesnastowiecznej lekcje śpiewu były obowiązkowe i odbywały się we wszystkich szkołach nawet po kilka godzin w tygodniu 4 . Sprzyjało to rozwojowi chórów szkolnych, które nierzadko osiągały wówczas bardzo wysoki poziom. Dzięki istnieniu tego rodzaju zespołów pogłębiały się również i upowszechniały praktyki domowego muzykowania, śpiewu a cappella bądź też z towarzyszeniem instrumentów ${ }^{5}$.

Bardzo dojrzałe poglądy na wychowawczą rolę muzyki głosił w Polsce wybitny uczony, filozof i pedagog, profesor Akademii Krakowskiej Sebastian Petrycy z Pilzna, który doceniał rolę pieśni w wychowaniu obywatelskim.

W drugiej połowie XVII wieku wyraźnie zmniejszyła się aktywność wielu ośrodków bujnego rozwoju muzyki. Ograniczono lekcje tego przedmiotu w szkołach, co odbiło się niekorzystnie na efektach dydaktycznych i artystycznych w zakresie wychowania muzycznego ${ }^{6}$. W czasach saskich brak zainteresowania rządzących edukacją muzyczną doprowadził do jeszcze większego zaniedbania w tej dziedzinie. Bursy muzyczne ${ }^{7}$, tworzone

${ }^{3}$ J. Prosnak, Polihymnia ucząca. Wychowanie muzyczne w Polsce od średniowiecza do dni dzisiejszych, Warszawa 1976, s. 12.

${ }^{4}$ Ibidem, s. 16.

${ }^{5}$ Ibidem, s. 17.

${ }^{6}$ Ibidem, s. 17.

${ }^{7}$ Ibidem, s. 34. 
przy niemal wszystkich kolegiach jezuickich, a także klasztor jasnogórski, częściowo wypełniły zaistniałą lukę. Pod okiem wykształconych pedagogów uczono w nich gry na różnych instrumentach, a także śpiewu wielogłosowego, dyrygentury i kompozycji. W bursach dominikańskich naukę gry na instrumentach klawiszowych, smyczkowych i dętych pobierali głównie uczniowie pochodzący z rodzin chłopskich i drobnej szlachty.

Warto wspomnieć, że zasadnicze zmiany w organizacji szkolnictwa w tym okresie zaszły dzięki działaniom pionierskiego reformatora szkolnictwa polskiego Stanisława Konarskiego. W opracowanych przez niego Ustawach szkolnych z 1755 roku znajdujemy zalecenia dotyczące nie tylko nauki śpiewu w szkołach, ale także nauki tańca, który, w myśl wskazań Platona, jako czynnik o doniosłym znaczeniu wychowawczym, miał kształcić i duszę, i ciało ${ }^{8}$. Słuszne i postępowe zalecenia zawarte w tych ustawach nie mogły być jednak w pełni zrealizowane ze względu na brak odpowiednich nauczycieli. W związku z tym w celu przygotowania kadry pedagogicznej powołano do życia specjalne uczelnie: seminaria nauczycielskie. Uczono w nich m.in. gry na organach i klawesynie. W myśl regulaminowych zaleceń działającej od 1773 roku Komisji Edukacji Narodowej, seminaria przygotowywały nauczycieli do dwóch zawodowych funkcji: pedagoga i muzyka - organisty. Uważano też, że nauczyciel powinien być wychowawcą nie tylko dzieci, lecz także rodziców, opiekunem społecznym o różnorodnych kompetencjach ${ }^{9}$.

W drugiej połowie XVIII wieku niezwykłe znaczenie dla krzewienia tych idei, również w Polsce, miała działalność wielu wybitnych pedagogów, m.in. Jana Amosa Komeńskiego propagującego nauczanie poglądowe, apelujące do zmysłów i spostrzeżeń dziecka. Niezwykle ważne sprawy dotyczące kształcenia muzycznego podkreślał też Jean Jacques Rousseau, wskazując na potrzebę rozwijania słuchu i wrażliwości muzycznej już we wczesnym dzieciństwie oraz zalecając tworzenie specjalnych pieśni dla dzieci, które przybliżą je najszybciej do rozumienia i umiłowania muzyki. Grzegorz Piramowicz domagał się respektowania w szkolnych programach nauczania pieśni, jako czynnika o niezwykle doniosłym znaczeniu dla wychowania. Z uwagi na trudną sytuację polityczną kraju Komisja kładła szczególny nacisk na obywatelskie i patriotyczne wychowanie oraz gotowość obronną młodzieży w szkołach, którymi administrowała. Zachowały

\footnotetext{
${ }^{8}$ Ibidem, s. 36.

${ }^{9}$ Ibidem, s. 59.
} 
się z tego czasu pieśni żołnierskie, pełne wychowawczych i patriotycznych treści. Ich walory podkreślił w 1798 roku wychowanek Szkoły Rycerskiej Tadeusz Kościuszko w liście do twórcy naszego hymnu narodowego Józefa Wybickiego: „Znasz, ile pieśni entuzjazmu wpajają w dusze ludzi, co dyszą za wolnością; chciej je pomiędzy współziomkami pomnażać”10. Również wiele dobrego dla muzycznej kultury w Polsce uczynił kanonik katedralny ks. Wacław Sierakowski, który nawoływał m.in. do dbałości o kulturę języka poprzez śpiewanie polskich pieśni.

Szczególną rolę odgrywała pieśń w okresie zaborów, kiedy to kultura miała utrwalać tradycje duchowe i uzbroić naród w siłę do walki.

W zaborze rosyjskim w istniejących szkołach (parafialnych, obwodowych i gimnazjach) uczono muzyki fakultatywnie, posługując się w tym celu śpiewnikami, m.in. zawierającymi pieśni polskich kompozytorów: Stanisława Moniuszki, Ignacego Komorowskiego i Zygmunta Noskowskiego (z tekstami Marii Konopnickiej).

W Wielkopolsce, w odpowiedzi na próby germanizacji w zaborze pruskim, pojawił się pierwszy polski śpiewnik szkolny opracowany przez Teofila Klonowskiego, a także wydano Śpiewy historyczne do tekstów Juliana Ursyna Niemcewicza, z muzyką kilkunastu polskich kompozytorów. Śpiewniki te, według Tadeusza Strumiłły, miały stanowić „pieśń masową średnich sfer”. Mimo nierówności poziomu muzycznego zawartych w nim utworów zbiór ten odegrał wielką rolę w utwierdzaniu poczucia narodowego i świadomości historycznej ${ }^{11}$.

W zaborze austriackim instrukcja wydana przez władze oświatowe, zawierająca wskazania do nauki śpiewu, zalecała łączenie nauki piosenek z nauką języka ojczystego, śpiewanie takich pieśni, które mają wartość pedagogiczną i zgadzają się z ogólnymi celami szkoły, czyli ludowych, narodowych i religijnych.

$\mathrm{Na}$ Pomorzu niezwykle ważne tradycje organizowania zespołów muzycznych sięgają drugiej połowy XIX wieku. Ucisk kulturalny i polityczny na tych terenach nie pozwalał na tworzenie jakichkolwiek stowarzyszeń, które miałyby na celu krzewienie polskiej kultury. Polscy działacze wykorzystywali jednak możliwości organizowania różnych sekcji kulturalnych przy legalnie działających towarzystwach przemysłowych. Z tych „śpiewających sekcji” powstały chóry, które nie tylko kultywowały polską pieśń, ale także

\footnotetext{
${ }^{10}$ Ibidem, s. 63.

${ }^{11}$ Ibidem, s. 100-102.
} 
organizowały przedstawienia teatralne, wycieczki, zabawy, odczyty czy dyskusje. Ruch śpiewaczy obejmował wówczas wszystkie warstwy społeczne, a najstarsze chóry w tych okolicach działały od 1869 roku. W Bydgoszczy zespół śpiewaczy powstał w roku 1872, a w 1885 roku odbył się w tym mieście pierwszy zjazd polskich kół śpiewaczych. Kolejne, organizowane cyklicznie, tego typu imprezy miały charakter nie tylko artystyczny, ale przede wszystkim narodowo-patriotyczny, gdyż dawały ich uczestnikom okazję do demonstrowania swojej polskości ${ }^{12}$.

Według Eugeniusza Rogalskiego ${ }^{13}$, w latach 1910-1912 tylko na Pomorzu istniało 27 chórów świeckich i 53 chóry kościelne, liczące łącznie 2740 śpiewaków, którzy dążyli do utworzenia związku śpiewaczego. Warto wspomnieć, że wiele chórów amatorskich nosiło imię Stanisława Moniuszki, animatora ruchu chóralnego w Wilnie i w Warszawie, autora Śpiewników domowych, których znaczenie dla kultury polskiej określił anonimowy poeta w następujących słowach: "Jeśli kiedy Polacy własną mowę zdradzą, polskim pieśniom Śpiewniki Twe umrzeć nie dadzą”.

Przekonanie o znaczeniu pieśni dla podtrzymania ducha narodowego i pielęgnowania języka kazało zwrócić uwagę działaczy ruchu chóralnego na odpowiedni repertuar tych zespołów. Zalecano uczenie chórzystów i wykonywanie przy różnych okazjach prostych pieśni jednogłosowych: ludowych krakowiaków, mazurów, polonezów, dumek i kołysanek. Śpiewanie ich w gronie rodzinnym miało służyć pomocą rodzicom w patriotycznym wychowywaniu dzieci, które w szkole były zmuszane do śpiewania pieśni niemieckich ${ }^{14}$.

W okresie międzywojennym w pierwszych po odzyskaniu niepodległości programach nauczania muzyki w szkołach powszechnych zalecano cały szereg ćwiczeń, mających pomagać w opanowaniu pieśni, a także różnych wiadomości m.in. $z$ harmonii, stylów muzycznych, form i literatury muzycznej. Nauka muzyki w pierwszych latach po wojnie była przedmiotem obowiązującym, wkrótce jednak ograniczono ją w klasach wyższych. W kolejnych programach $\mathrm{z}$ lat trzydziestych XX wieku zmniejszono wymagania dotyczące zagadnień teoretycznych i ćwiczeń, wskazując na zasadniczy cel przedmiotu o nazwie „śpiew”. Miał on przyczynić się do rozśpiewania dzie-

\footnotetext{
${ }^{12}$ J. Przybylski, Warunki rozwoju izadania amatorskiego ruchu śpiewaczego w Bydgoszczy w latach 1883-1920, „Studia z Wychowania Muzycznego” 1980, z. 4, s. 24-25.

${ }^{13}$ E. Rogalski, Funkcje wychowawcze amatorskiego ruchu chóralnego, Bydgoszcz 1978, s. $22-24$.

${ }^{14}$ J. Przybylski, Warunki rozwoju..., s. 27-28.
} 
ci, by aktywność ta stała się ich potrzebą życiową. Wybitnym działaczem był w owym czasie Stanisław Kazuro, muzyk i pedagog. Jego zasługą jest organizowanie chórów i zespołów, m.in. znanego wówczas chóru pod nazwą „300 Dzieci Powiśla”.

Niezwykle ważnym terenem muzycznych oddziaływań w tym okresie były też chóry: dziecięce, szkolne, robotnicze, wiejskie, inteligenckie, działające w całym kraju. W 1924 roku zapoczątkowano w Warszawie organizację dorocznego „Święta Pieśni”, które z czasem rozprzestrzeniło się na całą Polskę, a także objęło męskie, żeńskie i mieszane chóry szkół średnich. Repertuar ich był wyznaczany przez kuratoria, niekiedy też korzystano ze specjalnych publikacji lub śpiewników szkolnych, z których wiele ukazało się w tym okresie w Polsce. Warto też podkreślić, że działalność chórów i szerzenie kultury muzycznej propagował nasz wielki kompozytor Karol Szymanowski, a jego książka pt. Wychowawcza rola kultury muzycznej (pierwsze wyd.: Warszawa 1931) do dziś nie straciła aktualności w wielu sformułowaniach i spostrzeżeniach dotyczących tej formy aktywności.

Ogromne znaczenie dla rozwoju kultury muzycznej tego okresu miało też zwrócenie uwagi na tematykę lokalną w nauczaniu muzyki w szkołach powszechnych. Gorącym zwolennikiem odnowy tradycji regionalnych był Zygmunt Gloger. Regionalizm był w tym czasie postrzegany przez władze oświatowe jako ważny cel wychowawczy. W prasie pedagogicznej w tej sprawie wystąpił w 1930 roku Adolf Chybiński, który sprzeciwiał się rozprzestrzenianiu w programach szkolnych i podręcznikach „tandety muzycznej”. Postulował przygotowanie, na użytek szkół, odpowiedniej antologii pieśni ludowych różnych regionów. Sam był twórcą wzorcowego zbioru pt. Śpiewnik od Tatr do Bałtyku. A. Chybiński podkreślał też, że pieśn ludowa stanowi podstawę tego, co nazywamy pierwiastkiem narodowym w muzyce i te treści o wysokiej wartości trzeba zużytkować w wychowaniu narodowym. Uważał też, że młodzież w szkole ogólnokształcącej powinna poznawać polskie pieśni ludowe, które byłyby zawarte w specjalnie w tym celu stworzonym „elementarzu muzycznym” wydanym w formie przystępnej dla uczniów i nauczycieli ${ }^{15}$.

Tych kilka faktów wybranych z historii zwraca naszą uwagę na dbałość ówczesnych władz o szacunek dla narodowej kultury muzycznej, poprzez skuteczną i systematyczną edukację na miarę potrzeb społeczeństwa. Czyn-

${ }_{15} \mathrm{P}$. Dahling, Uwagi o regionalizmie muzycznym wszkolnictwie polskim okresu międzywojennego, „Wychowanie Muzyczne w Szkole” 2001, nr 5, s. 218. 
niki, które niekiedy hamowały czy utrudniały wówczas jej rozwój, miały raczej charakter polityczny, wynikający z zaistniałej sytuacji, w jakiej znalazł się nasz kraj (zabory, okupacje). W tych najtrudniejszych okresach naszego bytu śpiewanie polskich pieśni, organizowanie chórów i orkiestr, działalność stowarzyszeń kulturalnych, podtrzymywały naród na duchu, nie dając zginąć jego kulturze. Sytuacja, która obecnie niepokoi, ma jednak zupełnie inne źródło. Jest nim niezwykle intensywny od wielu lat napływ obcej kultury, nieznajdujący przeciwwagi w skutecznej edukacji, zarówno tej powszechnej, obowiązującej dzieci i młodzież, jak i tej, która jest przekazywana przez media. Współczesna edukacja muzyczna znalazła się niejako na uboczu wysokiej kultury, nie tylko wśród najszerszych warstw społeczeństwa, ale także wśród tych, którzy decydują o jej treściach. Niezwykle łatwy dostęp do wszelkiego rodzaju środków przekazujących muzykę doprowadził do tego, że muzyka, często mało wartościowa, jest obecna wszędzie i stanowi realne zagrożenie dla ogólnonarodowych wartości. Piękno jej ginie wśród masy dźwięków i hałasów, tworzących naszą „aurę akustyczną”, którą dosadnie określiła Zofia Konaszkiewicz: jako „świat intensywnie nasycony dźwiękami, ale bez muzyki”"16. Brak wyrobionego smaku muzycznego społeczeństwa jest powodem bezkrytycznego przyjmowania oferty mediów.

Należy sobie jednak zdawać sprawę z tego, że nie jest możliwe przerwanie napływu do nas obcej kultury. Nikt też nie wierzy w możliwość radykalnej zmiany w postawach i zainteresowaniach społeczeństwa, które można by porównać do „cudu”, polegającego na zmianie kierunku biegu rzeki. Realna ocena współczesnej sytuacji w edukacji i kulturze zmusza nas, zwłaszcza nauczycieli kształcących kadrę dla szkół ogólnokształcących, do refleksji nad wzorem osobowym nauczyciela, przygotowania go do tych działań, wyposażenia w wiedzę i umiejętności, które będzie przekazywał uczniom. To oczywiste, że dla wypełnienia tych zadań nie wystarczy tylko opanowanie zawodu czy wysokie wykształcenie, a także nawet uczciwa praca. Celem misji nauczyciela muzyki jest przekazywanie narodowych tradycji i uniwersalnej kultury przyszłym pokoleniom. Dokonuje się to w jego specjalnych działaniach podejmowanych wbrew trudnościom i oporom wychowanków, w dbałości o prawidłowe kontakty wychowawcze konieczne do osiągnięcia zamierzonych celów - kontakty te polegają na współpracy między nauczy-

\footnotetext{
${ }^{16}$ Z. Konaszkiewicz, Badania odbiorców muzyki - wnioski dla wychowania muzycznego i muzykoterapii, [w:] A. Białkowski (red.), Wychowanie muzyczne. Stan badań a praktyka edukacyjna, Lublin 1995, s. 184.
} 
cielem a uczniem i wzajemnym poszanowaniu, które jest warunkiem skutecznych działań wychowawczych.

Wspomniane $\mathrm{w}$ refleksji historycznej zagadnienia związane $\mathrm{z}$ sytuacją kultury muzycznej polskiego społeczeństwa ukazywały systematyczny kontakt ogółu uczniów z muzyką, obejmującą w czasach najbardziej korzystnych wszystkich, również młodzież akademicką. Dzięki temu muzyka trafiała do tych, którzy byli spragnieni jej piękna, natomiast mniej zainteresowanym dawała możliwość jej poznawania. Działające, mimo zakazu i trudności, chóry amatorskie, skupiały rzesze ludzi kochających muzykę. Prowadził je nauczyciel $w$ ramach wyuczonego zawodu, a także związana z nimi była jego społeczna działalność na rzecz kultury muzycznej. Wprawdzie z dokonanego tu przeglądu historii nauczania muzyki niewiele wiemy o osobowości nauczyciela jako takiej, a tylko o jego przygotowaniu zawodowym i podejmowanych działaniach, przedstawiona tu jednak wysoka ranga tego przedmiotu w oczach ówczesnych władz oświatowych i ich poparcie dla tej sfery wychowania podwyższały niejako autorytet nauczyciela w oczach uczniów i rodziców, co miało znaczenie dla efektów kształcenia i wychowania.

W refleksji nad nauczycielem nie można pominąć zagadnienia, które jest podkreślane w teoriach pedeutologicznych, a dotyczy konieczności „procesualnego" przygotowania nauczyciela do pracy. Wynika ona z właściwości osoby ludzkiej, która podlega ciągłemu rozwojowi ${ }^{17}$, w związku z czym żadna uczelnia nie jest w stanie przygotować nauczyciela do efektywnej pracy w zawodzie na całe życie. W tej profesji, jak również we wszystkich prestiżowych dziedzinach życia, ten, kto się nie rozwija, zostaje w tyle. Nauczyciel jest ciągle „w drodze”, a według Zenona Klemensiewicza „dobrym jest tylko ten nauczyciel, który wciąż staje się lepszym"18. Dlatego jest on zobowiązany do autoedukacji, rozwijania swoich zdolności przez całe życie, poprzez uczestnictwo w różnych przejawach życia muzycznego. Wrażliwość artystyczna nauczyciela, wynikająca z kontaktu z muzyką, powinna przekładać się na stosunki międzyludzkie, na kulturę współżycia i sposób traktowania uczniów. Te, i szereg innych specjalnych cech, uznanych za składniki osobowości nauczyciela muzyki różnią tych, którzy tylko „uczą” przedmiotu,

\footnotetext{
${ }^{17}$ R. Kwaśnica, Wprowadzenie do myślenia o nauczycielu, [w:] Z. Kwieciński, B. Śliwerski (red.), Pedagogika, t. 2, Warszawa 2007, s. 297.

${ }^{18}$ Cyt. za: A. A. Kotusiewicz, Kształcenie nauczyciela a problemy współczesnej edukacji, Warszawa 1989, s. 43.
} 
od tych, którzy „wychowują muzycznie”, kształtują wyobraźnię, wrażliwość, czyli pełnią szczególną misję.

Odwołanie do użytego tu pojęcia misji przywodzi na myśl określenie zawarte w klasycznej pozycji z zakresu pedeutologii. Prekursor nauki o nauczycielu i autor wielu prac z tej dziedziny Jan Władysław Dawid już przed stu laty mówił o „duszy nauczycielskiej”, która przejawia się w potrzebie i zdolności sympatyzowania, wzajemnego przenikania się, udzielania swoich i uczestniczenia w cudzych stanach duchowych, w dążeniu do zgodności, harmonii i jedności z duchowym życiem innych ${ }^{19}$. Ponieważ istota tego zawodu wyraża się w „człowieczym udzielaniu się drugiemu człowiekowi”, toteż nic, co „wywodzi się z osobowości nauczyciela nie pozostaje obojętne, jej ludzka jakość uwielokrotnia się w ludziach"20. Zdaniem Stefana Szumana $^{21}$, prawdziwy wychowawca powinien posiadać „bogatą osobowość”: bogatą i odważną moralnie, bogatą w miłość, dojrzałą, prawdziwą, a także pełną „bogactwa życia estetycznego i umysłowego”. Charakteryzując doskonałego nauczyciela i jego talent pedagogiczny, autor ten podkreśla dwa podstawowe warunki jego zaistnienia i przejawiania się. Pierwszym jest wspomniane już bogactwo jego własnej osobowości, drugim zaś sposób rozdawania tego bogactwa w umiejętnym oddziaływaniu na wychowanka. Bogaty wewnętrznie nauczyciel, dając siebie uczniom, pomnaża swoje dobra - osobowość, inteligencję, zainteresowania, pasję, a harmonijne współdziałanie tych elementów warunkuje i wzbogaca także jego osobowośćc ${ }^{2}$. W życzliwych i przyjaznych kontaktach nauczyciela z uczniami przejawia się właśnie "miłość dusz", która jest niezwykłą siłą pokonującą nawet wielkie trudności wychowawcze. I właśnie „miłość dusz” to nic innego jak podmiotowe traktowanie wychowanka, uznawanie jego prawa do własnego osądu i własnych zainteresowań, nienarzucanie mu swojego zdania i stanowiska, niezmienianie jego poglądów „na siłę”, w poczuciu wyższości. Dotyczy to bardzo delikatnej sprawy, zapoznawania uczniów z muzyką artystyczną poprzez wskazywanie alternatywy dla ich aktualnych zainteresowań. Jest to zdecydowanie najtrudniejsza misja nauczyciela: doprowadzenie ucznia do poznania wartościowej muzyki, gdyż „wolność wyboru bez

\footnotetext{
${ }^{19}$ J. W. Dawid, O duszy nauczycielskiej, [w:] Osobowość nauczyciela, zbiór rozpraw w opracowaniu W. Okonia, Warszawa 1959, s. 34.

${ }^{20}$ J. Legowicz, O nauczycielu. Filozofia nauczania i wychowania, Warszawa 1975, s. 41-45.

${ }^{21}$ S. Szuman, Talent pedagogiczny, [w:] W. Okoń (oprac. i wstęp), Osobowość nauczyciela, Warszawa 1959, s. 98-99.

${ }^{22}$ W. Okoń, Problem osobowości nauczyciela, [w:] idem (oprac. i wstęp), Osobowość nauczyciela, Warszawa 1959, s. 11.
} 
orientacji w świecie wartości i bez kompetencji - jest prawem pozornym”23. Nauczyciel powinien pełnić w tej dziedzinie rolę animatora, stwarzającego warunki samorealizacji wychowanka, wspomagania go we własnym rozwoju. Dlatego tak cenna wydaje się zachęta Marii Manturzewskiej do dzielenia się z uczniem przeżyciami związanymi ze słuchaną muzykąą, dająca szansę otwarcia go na wartości, których dotąd nie był świadomy. Należy pamiętać, że „dawanie świadectwa głoszonym wartościom jest na pewno ważniejsze od najbardziej nawet interesującego i wnikliwego ich przekazywania"25. Czynnikiem niezwykle ważnym w tych działaniach wychowawczych jest okazywanie szacunku i zrozumienia nauczyciela wobec przeżyć ucznia, które daje mu ulubiona przez niego muzyka. Najlepiej jeśli nauczyciel zainteresowanie ucznia tą muzyką potrafi uczynić punktem wyjścia do poznawania i przychylności wobec muzyki artystycznej. Trzeba mieć świadomość, że wychowanie słuchacza muzyki nie polega na tłumaczeniu mu trudnej i niezrozumiałej dla niego muzyki, lecz na kształtowaniu wobec niej pozytywnej postawy, na przyjęciu i interioryzacji tego, co otrzymuje od nauczyciela.

Praca nauczyciela muzyki natrafia jednak współcześnie na niezwykle trudne do pokonania bariery: opieszałość ludzi decydujących o kulturze i media. Likwidacja placówek kulturalnych, wstrzymywanie subwencji na rozwój wysokiej kultury to skutek wieloletnich zaniedbań w edukacji estetycznej. Osoby podejmujące w tej kwestii tak poważne decyzje należą do pokolenia, które postawiło na rozrywkę i w te formy działalności inwestuje, nie mając rozeznania w szerokiej kulturze muzycznej i wartościach wychowawczych, które ona niesie. Brakuje im tej postawy estetycznej, która jest niezbędna w naznaczonym szacunkiem podejściu do dóbr kultury i do właściwej oceny ich wartości, a także wyobraźni i wiedzy o znaczeniu muzyki dla wychowania oraz odpowiedzialności za przyszłość naszej rodzimej kultury.

Media różnego rodzaju poprzez swoją atrakcyjność bazują na słabości szkoły i jej stale ograniczanej możliwości docierania z wartościową muzyką

${ }^{23}$ M. Przychodzińska, Subkultura młodzieżowa. Muzyka pop a wychowanie muzyczne, [w:] A. Białkowski (red.), Wychowanie muzyczne. Stan badań a praktyka edukacyjna, Lublin 1995, s. 289.

${ }^{24} \mathrm{M}$. Manturzewska, Zdolności, kompetencje i postawy muzyczne naszej młodzieży w świetle wyników badań. Dyskusja, [w:] eadem (red.), Psychologiczne podstawy kształcenia muzycznego, Warszawa 1999, s. 104-105.

${ }^{25}$ M. Łobocki, Pomaganie nauczycielom w postrzeganiu ucznia jako osoby ludzkiej, [w:] W. Hörner, M. Szymański (red.), Nauczyciel i kształcenie nauczycieli. Zmiany i wyzwania, Warszawa 2005, s. 94-95. 
do wszystkich uczących się. Zaniedbały bardzo ważną funkcję, polegającą na wychowywaniu do kontaktu z wartościową muzyką nie tylko uczniów, ale także ogółu społeczeństwa. Twórcy programów próbują wmówić, że cały naród przejawia taki sam poziom potrzeb kulturalnych w zakresie muzyki, zainteresowany jest tylko rozrywką, a programy przeładowane taką właśnie muzyką są spełnieniem jego oczekiwań. Z niektórych badań wynika jednak, że inteligentna młodzież, również badani przeze mnie licealiści, mając możliwość wyrażenia swoich życzeń odnośnie do treści i rodzaju muzyki słuchanej na lekcjach, nie domagali się tylko kontaktu z muzyką rozrywkową, którą są zainteresowani, ale 48,42\% z nich wyraziła chęć poznawania w szkole również muzyki artystycznej ${ }^{26}$. Szkoda, że nie mają możliwości na tym poziomie edukacji rozwijania swoich zainteresowań ze względu na brak odpowiedniego przedmiotu.

Wykonywanie zawodu nauczyciela muzyki nie może ograniczać się tylko do pracy na lekcji. Misję transmitowania kultury powinien pełnić również nauczyciel w środowisku, w którym przyszło mu pracować. W uczelniach przygotowujących do zawodu preferuje się kształcenie dyrygentów, które nie ma jednak przełożenia na liczbę i poziom chórów, zarówno szkolnych, jak i amatorskich. Nauczyciel muzyki powinien dążyć do ożywienia tych cennych praktyk muzykowania w szkole i w środowisku, które w przeszłości skutecznie podtrzymywały tradycje i rozwijały muzycznie. Z moich wieloletnich doświadczeń i badań wynika, że aktualnymi członkami amatorskich chórów są osoby, które kiedyś w szkole zasmakowały w tej formie aktywności ${ }^{27}$, a wyniki moich badań metodą "analizy korespondencji” wykazały, że najcenniejszymi źródłami aktywności muzycznej młodzieży należącej przez wiele lat do chóru, zespołu instrumentalnego, grającej na instrumentach, są ich środowiska rodzinne czy rówieśnicze, w których wspólnie śpiewają ${ }^{28}$. Muzyka uprawiana w rodzinach w przeszłości towarzyszyła spotkaniom towarzyskim i rodzinnym, na których śpiewano pieśni artystyczne naszych czołowych kompozytorów, a także pieśni popularne, patriotyczne, historyczne, ludowe. Należy zadać sobie pytanie: czy śpiewanie pieśni, które zgodnie z zamysłem mądrych pedagogów miało dawać radość, pielęgnować i rozwijać język, ma teraz być zastąpione obcą polskiej kulturze muzyką? Na ogół trudno dziś zachęcić młodych ludzi do udziału

\footnotetext{
${ }^{26}$ E. Szubertowska, Edukacja a kultura muzyczna młodzieży, Bydgoszcz 2003, s. 157-164.

${ }^{27}$ Eadem, Muzyczna aktywność własna a świadoma percepcja muzyki młodzieży szkót średnich, Bydgoszcz 2002, s. 122-123.

${ }^{28}$ Eadem, Edukacja a kultura muzyczna..., s. 273.
} 
w chórach amatorskich, a przecież ta forma działania mogłaby okazać się dla nich szczególnie cennym sposobem spędzania wolnego czasu i kulturalną rozrywką. Poważnym powodem braku zainteresowania tą formą aktywności jest również ograniczanie godzin nauki muzyki w szkole, co nie rokuje nadziei na podjęcie przez nich tej formy aktywności w dorosłym życiu.

Podsumowując te rozważania, należy zauważyć, że sytuacja w omawianej dziedzinie jest niezwykle trudna. Nasze otoczenie, poglądy głoszone przez niektóre „autorytety”, sytuacja edukacji i silne działanie mediów nie stwarzają dogodnych warunków do szerzenia wysokiej kultury muzycznej, do pielęgnowania narodowych tradycji. Jestem za „nowym”, ale bez odcinania się od tradycji, gdyż stanowi ona ważny punkt odniesienia do wartości.

Zawód nauczyciela muzyki to podstawa i punkt wyjścia do pełnienia misji, ta zaś jest postawą, polegającą na świadomości celu i działaniach wnoszących w pseudokulturę wartościową muzykę, niezależnie od napotykanych trudności. Niezbędne warunki jej powodzenia stanowią zapał i zaangażowanie nauczyciela, jego wysoka kultura, zainteresowania, bogactwo wewnętrzne i ciągły rozwój. W krzewieniu kultury muzycznej i w szeroko pojętym współczesnym wychowaniu muzycznym społeczeństwa nauczyciel powinien mieć wsparcie sprzymierzeńców podobnych do tych, którzy w przeszłości dbali o kulturę muzyczną w narodzie. Mam tu na myśli rodziny, w których śpiewano pieśni podtrzymujące tradycję i wspomagające patriotyczne wychowanie dzieci i młodzieży, oraz władze oświatowe, zatroskane o poziom kształcenia nauczycieli i dostęp dzieci i młodzieży do nauki muzyki. Brak takiego wsparcia czyni posłannictwo współczesnego nauczyciela niezwykle trudnym i mało efektywnym.

Przekładając te treści na język wyobraźni, uświadamiam sobie, że sytuację kultury muzycznej można by przedstawić w formie piramidy, której mocną i szeroką podstawą winno być ogólnodostępne wychowanie muzyczne, uwzględniające wszystkie formy aktywności muzycznej i zróżnicowane zainteresowania wychowanków, realizowane przez odpowiednio wykształconych nauczycieli. Nie może zabraknąć na tym etapie edukacji kontaktu $\mathrm{z}$ wysoką kulturą muzyczną, gdyż tylko poznanie różnorodnej muzyki i przychylność wobec niej może być podstawą wykrystalizowania się rzeczywistych określonych upodobań czy zainteresowań słuchaczy. W tej najszerszej warstwie stanowiącej mocne fundamenty kultury muzycznej nie może zabraknąć również stymulacji rodziny, która jako pierwsza powinna uczyć polskich pieśni, zanim dziecko zostanie wyedukowane przez środki 
masowego przekazu. Coraz wyższe poziomy tej piramidy stanowią w moim odczuciu odpowiedniki elity, która na gruncie zdobytego w szkole szerokiego rozeznania w kulturze muzycznej, dokonała wyboru muzyki o wysokich walorach artystycznych i dąży do rozwijania w tym kierunku swoich zainteresowań. W tej warstwie powinni znaleźć się również nauczyciele muzyki, przygotowani do kontaktu z różnymi rodzajami muzyki i zdolni do prawidłowej estetycznej oceny tej, którą przekazują uczniom. Powinni też mieć świadomość ogromnej odpowiedzialności i doniosłości zadań, do których zostali powołani.

\section{Bibliografia}

Dahling P., Uwagi o regionalizmie muzycznym w szkolnictwie polskim okresu międzywojennego, „Wychowanie Muzyczne w Szkole” 2001, nr 5.

Dawid J. W., O duszy nauczycielstwa, [w:] Osobowość nauczyciela. Rozprawy J. Wt. Dawida, Z. Mysłakowskiego, St. Szumana, M. Kreutza, St. Baleya, oprac. i wstęp W. Okoń, Warszawa 1959.

Jankowski D., Edukacja kulturalna - aktywność artystyczna, Poznań 1996.

Konaszkiewicz Z., Badania odbiorców muzyki - wnioski dla wychowania muzycznego i muzykoterapii, [w:] A. Białkowski (red.), Wychowanie muzyczne. Stan badań a praktyka edukacyjna, Lublin 1995, s. 183-188.

Kotusiewicz A. A., Kształcenie nauczyciela a problemy współczesnej edukacji, Warszawa 1989.

Kwaśnica R., Wprowadzenie do myślenia o nauczycielu, [w:] Z. Kwieciński, B. Śliwerski (red.), Pedagogika, t. 2, Warszawa 2007.

Legowicz J., O nauczycielu. Filozofia nauczania i wychowania, Warszawa 1975.

Łobocki M., Pomaganie nauczycielom w postrzeganiu ucznia jako osoby ludzkiej, [w:] W. Hörner, M. S. Szymański (red.), Nauczyciel i kształcenie nauczycieli. Zmiany i wyzwania, Warszawa 2005.

Manturzewska M., Zdolności, kompetencje i postawy muzyczne naszej młodzieży w świetle wyników badań. Dyskusja, [w:] M. Manturzewska (red.), Psychologiczne podstawy kształcenia muzycznego, Warszawa 1999.

Okoń W., Problem osobowości nauczyciela, [w:] Osobowość nauczyciela. Rozprawy J. Wt. Dawida, Z. Mysłakowskiego, St. Szumana, M. Kreutza, St. Baleya, oprac. i wstęp W. Okoń, Warszawa 1959.

Prosnak J., Polihymnia ucząca. Wychowanie muzyczne w Polsce od średniowiecza do dni dzisiejszych, Warszawa 1976.

Przychodzińska M., Subkultura młodzieżowa. Muzyka pop a wychowanie muzyczne, [w:] A. Białkowski (red.),Wychowanie muzyczne. Stan badań a praktyka edukacyjna, Lublin 1995. 
Przybylski J., Warunki rozwoju i zadania amatorskiego ruchu śpiewaczego w Bydgoszczy w latach 1883-1920, „Studia z Wychowania Muzycznego” 1980, z. 4.

Rogalski E., Funkcje wychowawcze amatorskiego ruchu chóralnego, Bydgoszcz 1978.

Szubertowska E., Edukacja a kultura muzyczna młodzieży, Bydgoszcz 2003.

Szubertowska E., Muzyczna aktywność własna a świadoma percepcja muzyki młodzieży szkół średnich, Bydgoszcz 2002.

Szuman S., Talent pedagogiczny, [w:] Osobowość nauczyciela. Rozprawy J. Wt. Dawida, Z. Mysłakowskiego, St. Szumana, M. Kreutza, St. Baleya, oprac. i wstęp W. Okoń, Warszawa 1959.

Szymanowski K., Wychowawcza rola kultury muzycznej, Warszawa 1984. 